Hydraulic Engineering Repository

Ein Service der Bundesanstalt für Wasserbau

Kandaris, Peter M.; Wahlin, B.

Design of Laterally Loaded Deep Piers to Resist River Scour

Verfügbar unter / Available at:

https://hdl.handle.net/20.500.11970/100216

Vorgeschlagene Zitierweise / Suggested citation:

Kandaris, Peter M.; Wahlin, B. (2010): Design of Laterally Loaded Deep Piers to Resist River Scour. In: Burns, Susan E.; Bhatia, Shobha K.; Avila, Catherine M. C.; Hunt, Beatrice E. (Hg.): Proceedings 5th International Conference on Scour and Erosion (ICSE-5), November 7-10, 2010, San Francisco, USA. Reston, Va.: American Society of Civil Engineers. S. 777-786. 


\title{
Design of Laterally Loaded Deep Piers to Resist River Scour
}

\author{
P. M. Kandaris ${ }^{1}$, P.E. and B. Wahlin ${ }^{2}$, Ph.D., P.E., D.WRE
}

${ }^{1}$ Salt River Project, Mail Stop XCT317, P.O. Box 52025, Phoenix, AZ 85072-2025; PH (602) 236-8613; email: pmkandar@srpnet.com

${ }^{2}$ WEST Consultants, Inc., 8950 S. $52^{\text {nd }}$ St. Ste. 210, Tempe, AZ 85284; PH (480)

345-2155; email: bwahlin@westconsultants.com

\section{ABSTRACT}

Expansion of the $91^{\text {st }}$ Avenue Waste Water Treatment Plant in Phoenix, Arizona necessitated the relocation of a major Salt River Project (SRP) $500 \mathrm{kV}$ electric transmission power line. The project required installation of six reinforced concrete drilled shaft foundations at two structure sites within and along the Salt River banks to support the new single pole structures. WEST Consultants (WEST) performed hydraulic and sediment transport analyses to determine the local and longterm scour depths in the area near the supporting foundations. The hydraulic analysis consisted of determining average and maximum flow velocities as well as water surface elevations for various peak flow events. SRP utilized these values to determine the local scour that might be expected on the new foundations. WEST developed a sediment transport model for the study reach that was run through an observed 105-year flow hydrograph. Long-term scour near the new foundations was estimated from the sediment transport modeling results. WEST also conducted geomorphic analyses to evaluate the relative lateral stability of the channel in the vicinity of the proposed structures. SRP performed a geotechnical investigation to the full depth of proposed foundations to characterize subsurface soils and develop design parameters. Final design incorporating all study work resulted in the construction of $3-\mathrm{m}$ diameter foundations ranging from $21.0-\mathrm{m}$ to $23.9-\mathrm{m}$ in length, with maximum reveals from scour and associated bank ground loss of up to 16.1-m.

This paper discusses a probabilistic approach for design of deep pier foundations with large reveals where structures and their structural elements must resist the transient environmental conditions of wind, temperature and stream flow.

\section{INTRODUCTION}

The $91^{\text {st }}$ Avenue Wastewater Treatment Plant, located just north of the Salt River and east of $91^{\text {st }}$ Avenue in Phoenix, Arizona, treats wastewater from the cities of Phoenix, Glendale, Mesa, Scottsdale, and Tempe. Plant reclaimed water is used for agriculture, running the Palo Verde Nuclear Power Plant, and helping provide a wildlife refuge in the adjacent Tres Rios Demonstration Wetlands Project. As part of ongoing capital improvements, the plant is undergoing a multi-year expansion to boost capacity from 678 MLD to 772 MLD by 2014 .

A segment of the SRP Jojoba to Kyrene $500 \mathrm{KV}$ electric transmission power line extends through the planned waste water treatment plant expansion area and must be relocated to facilitate the work (see Figure 1). Work involves constructing five new structure sites using eleven single shaft poles that will wrap around the north, east, and south perimeters of the plant site and the demolition of two lattice tower 
structures within plant property. Two new structure sites (CP-128 and CP-128A) along the south boundary are within the north bank of the normally dry Salt River and require drilled pier reinforced concrete foundations to be built at the edge of the river's floodplain. Both sites will use three cylindrical steel shaft poles, each founded on a drilled shaft pier, to support the power lines. The western site (CP-128) will be constructed $60-\mathrm{m}$ southeast of an existing lattice tower structure within the same alignment as the present transmission line. The second site (CP-128A) is to be constructed approximately $365-\mathrm{m}$ east-northeast of the same lattice tower structure.

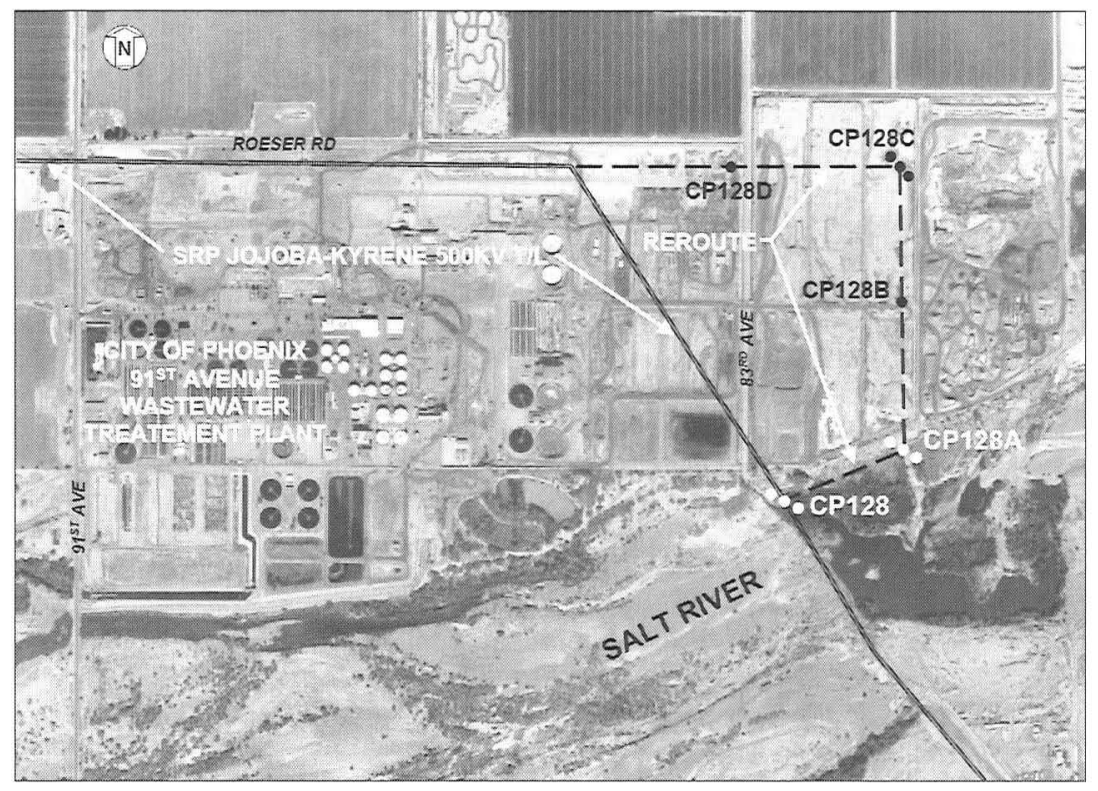

Figure 1. Site location.

Drilled shaft reinforced concrete foundations supporting poles must be designed to accommodate ephemeral river flow forces and corresponding ground loss from scour conditions along with maximum loads induced by electric power conductor lines from transient tension and wind loads. Structure design loads on foundations provided by the pole vendor are presented in Table 1 . These loads are maximum design values (ultimate loads) at the top of the piers that include appropriate electric code overload factors.

\section{Investigation Scope and Purpose}

Nominal 21-m deep exploratory borings were performed at each structure site. Holes were advanced by use of percussion drilling with a Becker diesel hammer drill rig, Model AP1000; hammer rated at a maximum energy of $11 \mathrm{kN}-\mathrm{m}$ per blow. Percussion testing was performed by counting the number of hammer blows required 
to drive the casing each $0.305-\mathrm{m}$ into the subsurface. Standard penetration resistance tests (SPT) were also obtained within the exploratory borings beginning about 12-m below grade and about every $1.5-\mathrm{m}$ thereafter for the full depth of each boring. Recovered samples were laboratory tested for soil strength properties and used along with blow counts to characterize the strata and estimate design properties.

Table 1. Foundation base plate loads (ultimate)

\begin{tabular}{c|c|l|c|c|c|c}
\hline \multicolumn{2}{c|}{ Structure } & Structure w/ & & \multicolumn{3}{c|}{ Reactions (maximum) } \\
\cline { 5 - 7 } Type & $\begin{array}{c}\text { Height } \\
(\mathbf{m})\end{array}$ & $\begin{array}{c}\text { foundation } \\
\text { number }\end{array}$ & Quantity & $\begin{array}{c}\text { Shear } \\
(\mathbf{k N})\end{array}$ & $\begin{array}{c}\text { Moment } \\
(\mathbf{M N}-\mathbf{m})\end{array}$ & $\begin{array}{c}\text { Compression } \\
(\mathbf{k N})\end{array}$ \\
\hline SPEC A & 42.7 & CP-128-1,3 & 2 & 558 & 21.27 & 400 \\
\hline SPEC B & 34.7 & CP-128-2 & 1 & 503 & 19.00 & 354 \\
\hline SPEC C & 42.7 & CP-128A-1, 3 & 2 & 502 & 16.20 & 341 \\
\hline SPEC D & 34.7 & CP-128A-2 & 1 & 458 & 14.36 & 283 \\
\hline
\end{tabular}

SRP employed WEST to perform hydraulic and sediment transport analyses for determining long-term degradation, parameters for use in local scour calculations at structure sites, and potential embankment loss. Hydraulic analyses were conducted for the 25-year, 100-year, and 500-year peak flow events. This analysis consisted of determining average and maximum flow velocities as well as water surface elevations for the various peak flow events. SRP then used these parameters to estimate the local scour that might be expected at the new foundations. WEST conducted a geomorphic and sediment transport analysis to evaluate the relative lateral stability of the channel in the vicinity of the proposed structures. Using existing HEC-6T sedimentation models developed for the Salt River, the general aggradation and/or degradation anticipated near the structure locations was also estimated.

\section{Site and Geologic Setting}

The site is on an elevated portion of the north bank of the Salt River and along the active flood channel bordering active and inactive sand and gravel mining operations. Two of the CP-128 foundations rest on a ridge at an elevation of $295-\mathrm{m}$ (above mean sea level). The third foundation is located within an existing irrigation tail water ditch that drains into the river channel (invert at about at elevation 294-m). The foundations at CP-128A are also near the top ridge of the bank, but also lie within a graded earth-fill/cut ramp that extends down into the river channel (part of the mining operation). Ground elevations near these foundations range from about $300-\mathrm{m}$ on the north end to $297-\mathrm{m}$ on the south end. The steep bank of the river (primarily the result of mining operations) borders structure locations and the new transmission line alignment to the south, dropping down to a lower high-flow portion of the channel at an average elevation of 294-m. Invert elevations within numerous adjacent incised low-flow channels within the main river range from 290-m to 292-m.

Near-surface soil in the floodplain of the Salt River is primarily composed of recent alluvial deposits (Holocene to perhaps locally late Pleistocene) at least $18-\mathrm{m}$ in thickness that overlay basin fill deposits (Demsey, 1989). Uppermost alluvium represents recent floodplain deposits, perhaps with minor aeolian and locally derived components and is mostly poorly graded silty sand, sand, gravelly sand, and gravel 
with occasional interlayers of silt and silty clay (Fugro, 1979). Below this veneer is a very coarse and unconsolidated gravel unit mostly containing pebbles, cobbles, and boulders within a sandy matrix. The gravel (referenced as the Salt River Gravels) unit includes clasts of rocks not found in local mountains and represents deposits of the Salt River (Reynolds and Bartlett, 2002). These gravels have a siltier matrix in some areas, but lack any sandy or silty matrix found in some very coarse channel deposits.

\section{ANALYSIS}

\section{Subsurface Characterization}

Variable thickness layers of upper alluvium are encountered to a depth of 5.0-m at CP-128 and 5.5-m at CP-128A and are comprised of loose to medium dense (dense near the bottom of the deposit) non-plastic silty and gravelly sand and sandy gravel. Very dense, non-plastic sand/gravel/cobble deposits (locally referred to as SGC) underlay these upper strata to the full depth of borings. Interbedded within this SGC deposit are small fine-grained lenses of stiff, low plasticity clayey-silty sand to sandy silty clay and medium-dense to dense non-plastic sands ranging in thickness from $0.6-\mathrm{m}$ to $1.5-\mathrm{m}$. These lenses are primarily found at the following intervals below grade: $8.8-\mathrm{m}$ to $9.8-\mathrm{m}, 12.2-\mathrm{m}$ to $13.1-\mathrm{m}$, and $17.4-\mathrm{m}$ to $18.9-\mathrm{m}$.

Groundwater was encountered during the investigation at $7.3-\mathrm{m}$ below grade at $\mathrm{CP}-128$ and at 9.8-m below grade at CP-128A. High groundwater levels within the active river channel and the surrounding floodplain have developed in response to recharge induced by long-term runoff and effluent from the adjacent wastewater plant in the normally dry river channel. A reduction in water level typically occurs soon after runoff ceases due to the highly permeable nature of river sediments. However, inundation and saturation of the entire soil column at structure locations can be expected periodically, thereby causing groundwater level fluctuations (Fugro, 1979).

Blow counts along with bore log subsurface soil descriptions are used to create an idealized subsurface soil profile for the site. The idealized soil layers are assigned low-bound normalized blow count values by statistical analyses that are then correlated with soil strength and deformation properties. A summary of the site geotechnical properties and design parameters assumed is presented in Table 2.

\section{Previous Hydraulic and Sediment Transport Analyses}

WEST performed two previous studies for the U.S. Army Corps of Engineers (USACE) in the area: the Rio Salado Oeste Feasibility Study (WEST, 2002) and the Preconstruction Engineering and Design (PED) of the Tres Rios North Levee (WEST, 2004). The Rio Salado project was a hydraulic and sediment transport analysis of the Salt River from $19^{\text {th }}$ Avenue to $91^{\text {st }}$ Avenue. The Tres Rios project provided a hydraulic PED for the proposed Tres Rios North Levee. The project reach included the Salt and Lower Gila Rivers in Phoenix, AZ, extending from the Agua Fria River confluence to $91^{\text {st }}$ Avenue. For both of these studies, WEST created a hydraulic model using HEC-RAS and a sediment transport model using HEC-6T. The hydraulic model for the Rio Salado Oeste project was developed using 1.2-m contours. The various sand and gravel mining pits in the area were included as part of the topography when the cross-sections were generated. The hydraulic model for the Tres 
Rios project was subdivided into three reaches: the Salt River, the Upper Gila River, and the Lower Gila River. The elevation data used to construct the Tres Rios hydraulic model consisted primarily of $0.3-\mathrm{m}$ vertical resolution topography.

Table 2. Geotechnical properties and design parameters

\begin{tabular}{|c|c|c|c|c|c|c|c|c|c|}
\hline Property/Value & $\begin{array}{c}\text { Silty \& } \\
\text { gravelly } \\
\text { sands }\end{array}$ & $\begin{array}{l}\text { Very } \\
\text { dense } \\
\text { SGC } \\
\end{array}$ & Sand & $\begin{array}{l}\text { Dense } \\
\text { SGC }\end{array}$ & Sand & $\begin{array}{l}\text { Dense } \\
\text { SGC }\end{array}$ & $\begin{array}{l}\text { Very } \\
\text { dense } \\
\text { SGC } \\
\end{array}$ & $\begin{array}{c}\text { Silts } \\
\& \\
\text { clays }\end{array}$ & $\begin{array}{l}\text { Dense } \\
\text { SGC }\end{array}$ \\
\hline Depth, (m) & 0 to 5 & 5 to 9 & 9 to 10 & \begin{tabular}{|c|}
10 to \\
12 \\
\end{tabular} & $\begin{array}{c}12 \text { to } \\
13\end{array}$ & $\begin{array}{l}13 \text { to } \\
14.3\end{array}$ & $\begin{array}{c}14.3 \text { to } \\
17.4\end{array}$ & $\begin{array}{l}17.4 \\
\text { to } 19 \\
\end{array}$ & +19 \\
\hline $\begin{array}{l}\text { SPT Blow Count, } \\
\text { (blows } / 0.305 \mathrm{~m} \text { ) }\end{array}$ & 39 & 97 & 10 & 78 & 16 & 63 & 94 & 12 & 57 \\
\hline $\begin{array}{l}\text { Total Unit } \\
\text { Weight, }\left(\mathrm{kg} / \mathrm{m}^{3}\right)\end{array}$ & 1922 & 2162 & 1682 & 2162 & 1682 & 2162 & 2162 & 1602 & 2162 \\
\hline $\begin{array}{l}\text { Friction Angle, } \\
\text { (deg) }\end{array}$ & 34 & 50 & 30 & 45 & 31 & 42 & 47 & 30 & 41 \\
\hline Cohesion, (MPa) & 0 & 0 & 0 & 0 & 0 & 0 & 0 & 0 & 0 \\
\hline $\begin{array}{l}\text { Strength } \\
\text { Reduction Factor }\end{array}$ & 1.00 & 0.70 & 1.00 & 0.80 & 1.00 & 0.86 & 0.76 & 1.00 & 0.88 \\
\hline $\begin{array}{l}\text { Elastic Modulus, } \\
(\mathrm{MPa})\end{array}$ & 27.6 & 55.2 & 6.2 & 48.3 & 12.4 & 41.4 & 855.2 & 5.5 & 37.9 \\
\hline
\end{tabular}

\section{Hydrology}

The hydrology for the study is based on a report from the USACE (1996). Values for the 5-year through 500-year peak discharges are shown in Table 3.

\section{Hydraulics}

Because the study area is located right at the break between the two individual models, the Rio Salado Oeste model and the Tres Rios model were combined into a single HEC-RAS model to compute maximum water surface elevations, flow depths, flow velocities, and flow distributions for the 500-, 100-, and 25-year peak flow events. By combining the two models, the effects of the sand and gravel mining operations upstream of the study area and the backwater effects from the proposed levee near the study site were evaluated simultaneously. The cross-sections where the transmission structures are proposed in both the hydraulic model and sediment model are shown in Table 4 . A summary of the hydraulic results appears in Table 5.

\section{Geomorphic Analysis}

The goal of the geomorphic analysis was to identify historical behavior of the Salt River by the collection and review of historical aerial photographs and the application of geomorphic relationships. A qualitative analysis of historical changes to river morphology was followed by a quantitative analysis for basic geomorphic factors of the Salt River. The Salt River was a perennial stream prior to construction of upstream water supply dams in the period 1908-1930. Historical accounts and photographs indicate that the Salt River was a wide braided channel that supported significant vegetation but was also prone to major flood events. Since completion of 
the upstream dams on the Salt and Verde Rivers, the study reach has experienced significant periods of virtually no flow and is now an intermittent stream.

Table 3. Peak discharges used for hydraulic analysis (USACE, 1996)

\begin{tabular}{c|c}
\hline Event & Flow rate $(\mathrm{cms})$ \\
\hline 500-year & 6,655 \\
\hline 100-year & 4,587 \\
\hline 50-year & 3,737 \\
\hline 25-year & 2,633 \\
\hline 20-year & 2,378 \\
\hline 10-year & 1,444 \\
\hline 5-year & 566 \\
\hline \multicolumn{2}{|c}{ Interpolated from 20 - \& 50-yr events. }
\end{tabular}

Table 5. Hydraulic results at the various structure locations

\begin{tabular}{l|c|c|c|c|c}
\hline $\begin{array}{c}\text { Structure } \\
\text { location }\end{array}$ & $\begin{array}{c}\text { River } \\
\text { Station }\end{array}$ & $\begin{array}{c}\text { Water } \\
\text { surface } \\
\text { elev. }(\mathrm{m})\end{array}$ & $\begin{array}{c}\text { Maximum } \\
\text { channel } \\
\text { depth }(\mathrm{m})\end{array}$ & $\begin{array}{c}\text { Average } \\
\text { velocity } \\
(\mathrm{m} / \mathrm{s})\end{array}$ & $\begin{array}{c}\text { Maximum } \\
\text { velocity } \\
(\mathrm{m} / \mathbf{s})\end{array}$ \\
\hline $\mathbf{2 5 - y e a r}$ flows \\
\hline CP-128 & 203.48 & 296.95 & 5.00 & 2.32 & 2.81 \\
\hline CP-128A & $203.67 / 203.77$ & 297.36 & 3.98 & 1.59 & 1.91 \\
\hline 100-year flows \\
\hline CP-128 & 203.48 & 297.78 & 5.83 & 2.90 & 3.37 \\
\hline CP-128A & $203.67 / 203.77$ & 298.27 & 4.90 & 1.99 & 2.37 \\
\hline 500-year flows & 203.48 & 298.47 & 6.52 & 3.34 & 3.79 \\
\hline CP-128 & $203.67 / 203.77$ & 299.01 & 5.66 & 2.42 & 2.85 \\
\hline CP-128A &
\end{tabular}

The shifting, changing nature of braided channels and the fact that they are often generated by sediment deposition and bed aggradation leads many engineers and river scientists to associate them almost exclusively with disequilibrium in the fluvial system. However, as Leopold et al. (1964) pointed out, braided river systems are a distinct and viable category of dynamically stable planform, along with straight and meandering systems. The recent historical evidence examined here indicates that the project reach is in quasi-equilibrium, although adjustments to bank and thalweg lines within the historical meander belt are possible.

\section{Sediment Transport Analysis}

WEST estimated the general aggradation and/or degradation at the structure locations by combining the Rio Salado Oeste and the Tres Rios HEC-6T sediment transport model developed for the Salt River.

Hydrologic data for the simulation are taken from the more recent Tres Rios study and are comprised of a 105-year (1889-1993) series of hydrographs. Inflowing load from the Rio Salado Oeste model is used for each of the runs, because 
introducing the lower Tres Rios inflowing load at the upstream end of the Rio Salado Oeste model is not consistent with the bed gradations in the Rio Salado Oeste model. The model is run using the Yang stream power sediment transportation function and the Toffaleti-Meyer-Peter-Muller combination sediment transport function. The worst case of all the runs was used to evaluate the potential degradation at the structure locations. In addition, a run was made in which the inflowing sediment load was cut in half to evaluate the sensitivity of the expected degradation.

The recommended scour depth and elevation due to long-term degradation are provided in Table 6 . Total embedment depths for the structure foundation must also include a local scour component, which is not included in Table 6 (local scour is calculated as part of the foundation design). The sum of scour components (long-term degradation and local scour) should be subtracted from the minimum channel elevation to compute the maximum scour elevation to account for possible thalweg migration within channel banks.

Table 6. Recommended long-term degradation depths

\begin{tabular}{l|c|c|c}
\hline $\begin{array}{c}\text { Structure } \\
\text { location }\end{array}$ & $\begin{array}{c}\text { Thalweg } \\
\text { elev. }(\mathrm{m})\end{array}$ & $\begin{array}{c}\text { Recommended long-term } \\
\text { degradation depth (m) }\end{array}$ & $\begin{array}{c}\text { Recommended long-term } \\
\text { degradation elev. (m) }^{1}\end{array}$ \\
\hline CP-128 & 291.9 & -2.1 & 289.8 \\
\hline CP-128A & 293.2 & -0.9 & 292.3 \\
\hline
\end{tabular}

${ }^{1}$ The local scour component (pier scour) is not included in estimated values.

\section{FOUNDATION DESIGN}

Foundations must resist lateral forces introduced by wind on the conductors and pole, tension from conductors at angles that vary based on ambient temperature, and moving water on the foundation itself during periodic stream flow. The transient environmental factors of wind, temperature and water flow can be evaluated in terms of their maximum probable event frequency, with the understanding that peak wind and minimum temperature do not necessarily occur simultaneously with peak river flow. The goal is to match appropriate maximum probable events based upon time of year to provide a more reliable estimate of loads (a reliability-based approach). Maximum probable wind events, minimum expected temperatures and tension loads are governed by the National Electric Safety Code (NESC). Since the electric industry has no standard for hydraulic loads on foundations, SRP assumes a similar frequency for river flow events with foundation design. Project foundations are designed based on the largest dimensions provided by the following load cases.

- Case 1: Full bank washout + full long-term degradation + 100-yr event pier scour with NESC light wind loading on conductors and pole structures $(\approx 25 \mathrm{yr}$ return interval, ambient temperature at $-1.1^{\circ} \mathrm{C}$ ).

- Case 2: Full bank washout + full long-term degradation + 25-yr event pier scour with NESC extreme wind event on conductors and pole structures (100yr return interval, ambient temperature at $15.6^{\circ} \mathrm{C}$ ).

Water surface elevations, maximum flow velocities, and upstream channel depth values are obtained from Table 5. Embankment loss plus channel degradation values are obtained from the last column in Table 6. Top of piers are set above the 
500 -year event water surface elevations and at least $0.6-\mathrm{m}$ above existing high adjacent grade (whichever is higher) or at elevation 298.9-m for CP-128 and elevation 300.1-m for CP-128A.

A $3-\mathrm{m}$ diameter pier is used to accommodate the pole anchor bolt cage diameter and pier reinforcement clearance needs. The Colorado State University (CSU) equation is used in the analysis for determining local pier scour (FHWA equation 6.1, 2001). Other components of scour such as bend scour and contraction scour are not appropriate for this case.

Local design practice sets CSU equation constants as follows: $\mathrm{k}_{1}=1.0$ (round piers), $\mathrm{k}_{3}=1.1$ and $\mathrm{k}_{4}=1.0$, The spacing effect in relation to the approach angle of flow is considered since there are three foundations within close proximity. To account for group effects, the term $\mathrm{K}_{S} \mathrm{~K}_{\Theta}$, a combined shape and alignment factor for foundation groups, is substituted for $\mathrm{k}_{2}$ (Melville and Coleman, 2000). Foundations are to be spaced (S) 17-m apart on a 45 degree angle to the direction of flow. Assuming a maximum pier diameter (D) of $3-\mathrm{m}(\mathrm{S} / \mathrm{D}=5.5), \mathrm{K}_{\mathrm{S}} \mathrm{K}_{\Theta}$ is equal to 1.17.

Lateral forces control the design of single shaft electric transmission line structures. These forces introduce high moments with moderate shear forces upon the tops of support foundations. Exposed portions of piers (including lengths in the scour zone) are also subject to additional longitudinal load due to stream pressure. To simplify the analysis, stream pressure forces from each load case are converted to an equivalent single shear force at the top of the foundation in the downstream direction. Detailed calculation methods are found in the literature (Kandaris et al., 2002). Since the channel can migrate to foundation locations, it is assumed that all scour originates at the thalweg elevations noted in Table 6. Lateral load analysis of the foundation includes the long-term degradation shown in Table 6 and local scour calculated for each case. Figure 2 shows an example configuration. Table 7 summarizes the local scour and stream pressure forces for each case.

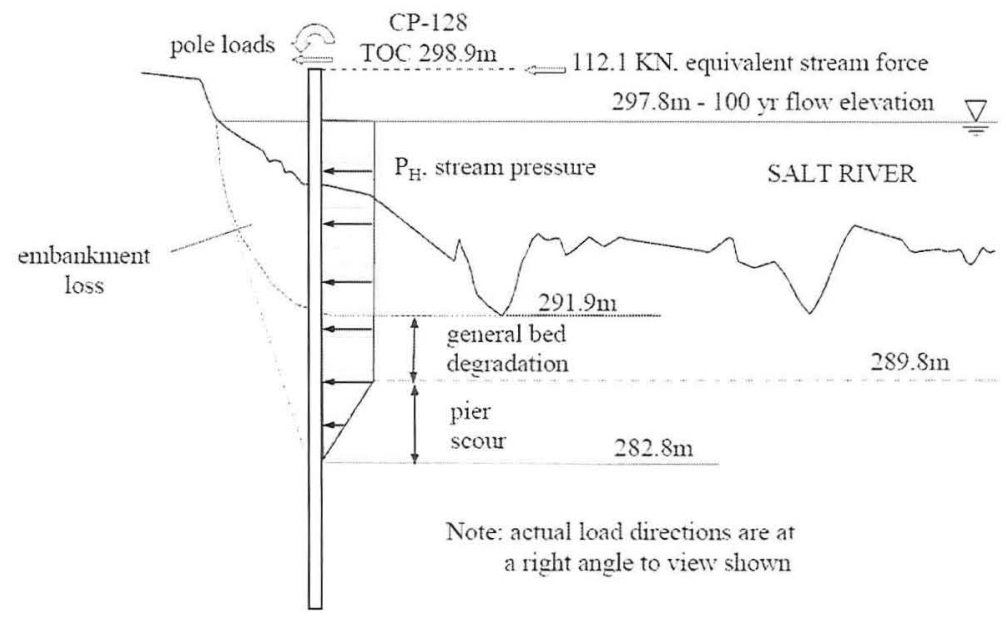

Figure 2. Scour and stream force model. 
Table 7. Local scour and stream pressure design values

\begin{tabular}{c|c|c|c|c}
\hline $\begin{array}{c}\text { Structure } \\
\text { number }\end{array}$ & $\begin{array}{c}\text { Scour } \\
\text { Event }\end{array}$ & $\begin{array}{c}\text { Local pier } \\
\text { scour depth } \\
(\mathbf{m})\end{array}$ & $\begin{array}{c}\text { Length of pier } \\
\text { above scour } \\
(\mathbf{m})\end{array}$ & $\begin{array}{c}\text { Equivalent water shear } \\
\text { force at top of foundation } \\
(\mathbf{k N})\end{array}$ \\
\hline \multirow{2}{*}{$\mathrm{CP}-128$} & $100-\mathrm{yr}$ & 7.0 & 16.1 & 112.1 \\
\cline { 2 - 5 } & $25-\mathrm{yr}$ & 6.3 & 15.4 & 66.0 \\
\hline \multirow{2}{*}{$\mathrm{CP}-128 \mathrm{~A}$} & $100-\mathrm{yr}$ & 5.9 & 13.7 & 40.0 \\
\cline { 2 - 5 } & $25-\mathrm{yr}$ & 5.2 & 13.0 & 20.4 \\
\hline
\end{tabular}

Foundation design results are summarized in Table 8 . These dimensions are determined by applying the ultimate base reaction values with factored stream pressure forces. The combined loads are then multiplied by a dead-end geotechnical load condition factor of safety of 1.25 to account for soil variability, load repetition, long-term loading and to ensure equal to or greater foundation reliability than the pole structure. Rotational movement at the top of the pier is limited to one degree. Electric Power Research Institute Foundation Analysis and Design (FAD) methodology and computer software is utilized to perform detailed calculations.

Table 8. Foundation dimension summary

\begin{tabular}{l|c|c|c|c}
\hline $\begin{array}{l}\text { Structure w/ } \\
\text { foundation } \\
\text { number }\end{array}$ & $\begin{array}{c}\text { Scour } \\
\text { Event }\end{array}$ & $\begin{array}{c}\text { Elevation to soil } \\
\text { resistance } \\
(\mathbf{m})\end{array}$ & $\begin{array}{c}\text { Foundation } \\
\text { embedment depth } \\
\text { below scour }(\mathrm{m})\end{array}$ & $\begin{array}{c}\text { Total pier } \\
\text { length }(\mathrm{m})\end{array}$ \\
\hline \multirow{2}{*}{$\mathrm{CP}-128-1,3$} & $100-\mathrm{yr}$ & 282.8 & 7.8 & $\mathbf{2 3 . 9}$ \\
\cline { 2 - 5 } & $25-\mathrm{yr}$ & 283.5 & 7.9 & 23.3 \\
\hline \multirow{2}{*}{$\mathrm{CP}-128-2$} & $100-\mathrm{yr}$ & 282.8 & 7.4 & 23.5 \\
\cline { 2 - 5 } & $25-\mathrm{yr}$ & 283.5 & 7.4 & 22.8 \\
\hline \multirow{2}{*}{$\mathrm{CP}-128 \mathrm{~A}-1,3$} & $100-\mathrm{yr}$ & 286.4 & 7.6 & 21.3 \\
\cline { 2 - 5 } & $25-\mathrm{yr}$ & 287.1 & 8.0 & 21.0 \\
\hline \multirow{2}{*}{$\mathrm{CP}-128 \mathrm{~A}-2$} & $100-\mathrm{yr}$ & 286.4 & 7.3 & 21.0 \\
\cline { 2 - 5 } & $25-\mathrm{yr}$ & 287.1 & 7.0 & 20.0 \\
\hline
\end{tabular}

Controlling cases shown in bold text.

\section{CONCLUSIONS}

A methodology is presented to determine total pier embedment for electrical transmission line foundations placed within an ephemeral river channel. The methodology takes into account loading due to flowing water, scour due to bank loss, forces due to wind, and the subsurface characteristics of the river bed. Hydraulic and sediment transport analyses are used to calculate long-term degradation, bank loss from stream migration and local scour around the piers. In this case, other scour components such as bend scour are not applicable; however, these components should be added if appropriate at a given site. Field geotechnical and geologic investigation work characterize subsurface conditions, allowing development of soil strength and deformation parameters for use in lateral load analyses.

The case history shown applies reliability-based principles that take into account two different transient load scenarios: the maximum probable peak stream 
flow event in conjunction with the seasonal high wind event and minimum low temperature condition; and a seasonal medium stream flow event with the maximum probable high wind event and seasonal low temperature condition. The lengths of the various 3-m diameter drilled shaft piers supporting structures CP-128 and CP-128A determined by the combined load and scour analyses range from $21.0-\mathrm{m}$ to $23.9-\mathrm{m}$. Portions of piers extending above total scour elevations range from $13.0-\mathrm{m}$ to $16.1-\mathrm{m}$.

Anderson Construction began drilling at CP-128A-1 on November 30, 2009 and completed their last concrete placement at CP-128-1 on February 3, 2010. Each pier foundation required an average of 5 working days to excavate and pour concrete to the planned cold joint within 3-m of ground surface. Use of both permanent metal liners and temporary steel casing above scour depths in conjunction with polymer slurry stabilization below scour depths held average foundation diameters within 3 percent of neat line values.

\section{REFERENCES}

Demsey, K.A. (1989). Geologic map of quaternary and upper tertiary alluvium in the Phoenix South 30'x 60' Quadrangle, Arizona. Arizona Geologic Survey (AZGS) OFR 89-7, Tucson, AZ.

Federal Highway Administration (FHWA) (2001). Evaluating scour at bridges. $4^{\text {th }}$ Ed., HEC 18, Pub. No. FHWA-NHI 01-001. Washington, D.C.

Fugro, Inc. (1979). Palo Verde to Kyrene transmission line. Salt River Project File Report CE-15, Phoenix, AZ.

Kandaris, P.M., Kondziolka, R.E., and Adams, J. P. (2002). "Design and construction of scour foundations for electric power transmission line structures." Proc. ICFS-1, Vol. 2, College Station/TX: 954-967.

Leopold, L.B., Wolman, M.G., and Miller, J.P. (1964). Fluvial processes in geomorphology. W.H. Freeman and Co., San Francisco, CA.

Melville, B.W., and Coleman, S.E. (2000). Bridge scour. Water Resources Publications, LLC, Highlands Ranch, CO.

Reynolds, S.J. and Bartlett, R.D. (2002). Subsurface geology of the easternmost Phoenix Basin, Arizona: implications for groundwater flow. AZGS CR-02-A, Tucson, AZ.

USACE (1996). "Section 7 Study for Modified Roosevelt Dam, Arizona (Theodore Roosevelt Dam)." Hydrologic Evaluation of Water Control Plans Salt River Project to Gila River at Gillespie Dam, USACE Los Angeles District.

WEST Consultants, Inc. (2004). PED Hydraulic Design of Tres Rios North Levee, Maricopa County, Pre-Final Project Analysis Final Report. Prepared for the U.S. Army Corps of Engineers, Los Angeles District, Contract Number DACW09-00-D-0021.

WEST Consultants, Inc. (2002). Rio Salado Oeste Study without Project Final Hydraulic Analysis Report. Prepared for the U.S. Army Corps of Engineers, Los Angeles District, Contract Number DACW09-00-D-0021. 